\title{
Specific effects of certain salts on carbohydrate metabolism in young corn seedlings
}

\author{
MOHAMMAD HATATA *, MICHEL FARAH ** \\ * Botany Department, Faculty of Science, University of Alexandria, \\ Moharram-Bey, Alexandria, Egypt \\ ** Salinity Laboratory, Bacos, Alexandria, Egypt
}

(Received: May 18, 1981)

\begin{abstract}
The effects of sodium and magnesium chlorides and sulphates on carbohydrate metabolism of corn seedlings and their component parts were studied. There was a decrease in the total carbohydrate content of seedlings with advance of time, in control and in different concentrations of salts. The decrease became less marked with increase of salt concentrations. The main effect of salinization, on the changes in carbohydrates, was strongest on the roots and grains. The roots contained the lowest proportion of the various carbohydrate fractions. This feature suggests that the mobilization of carbohydrates from grains to roots is greatly retarded by salinization. Both cations and anions exert an influence on the conversion of reserve carbohydrates.
\end{abstract}

\section{INTRODUCTION}

Salinity is known to retard plant growth through its influence on: e.g. osmotic adjustment (B e r n a l et al. 1975), ion uptake ( $\mathrm{Gr}$ e e n w a y et al. 1966), and hormonal balance ( $\mathrm{t} \mathrm{a}$ i et al. 1968). $\mathrm{C} \mathrm{h}$ o o $\mathrm{n} \mathrm{M} \mathrm{in} \mathrm{k} \mathrm{im}$ (1958), mentioned that the effects of salts in reducing crop plant growth probably came from one or more different sources: first, the direct physical effects of the salts in preventing water uptake; second, direct chemical effects of the salt in disturbing the nutrition and metabolism of plants; and third, the indirect of salt in altering the soil structure, permeability and aeration.

Earlier studies of salt effects were restricted to the changes in growth rate or morphological and anatomical changes rather than the changes in metabolic processes. The metabolic changes in plants grown under normal conditions are known fairly well. It is acknowledged that the nitrogen and carbohydrate metabolism of plants reflects the physio- 
logy of the whole plant, as well as interaction with its surroundings. On the other hand, the changes in carbohydrate and nitrogen metabolism of plants grown under saline conditions are still poorly investigated. Studies devoted to this question usually are based upon a quantitative comparison of the polysaccharides and protein contents and content of soluble carbohydrate fractions and non-protein nitrogen compounds in plants.

In this paper, therefore, an attempt is made to explore the effects of certain salts on the change of carbohydrate fractions in young corn seedlings. The salts chosen for the study are: sodium chloride, sodium sulphate, magnesium chloride and magnesium sulphate.

\section{MATERIAL AND METHODS}

The experimental procedure used was the same as described by $\mathrm{Hatata}$ and $\mathrm{Farah}$ (1982). Therefore, we note here only differences concerning sugars estimation.

Soluble sugars were extracted by boiling fine ground plant material in $80 \%$ ethanol as described by $\mathrm{K}$ a r moke r and $\mathrm{V}$ an $\mathrm{Stevenink}$ (1979). The extracts were diluted with water and kept for estimation of alcohol-soluble sugars, while the residue was dried for the determination of insoluble polysaccharides.

Reducing sugars were determined by evaluating the direct reducing value following the procedure described by Som o gy i (1952). Sucrose was determined as above after hydrolysis with invertase. The other nonreducing sugars content was deduced by subtracting the amount of reducing sugars and sucrose from the total reducing sugar content. The insoluble polysaccharides were determined in the same way after hydrolysis of the dried residue with $1 \mathrm{~N} \mathrm{HCl}$.

\section{RESULTS}

The effects of $0,1,10$ and $20 \mathrm{meq} / \mathrm{NaCl}, \mathrm{Na}_{2} \mathrm{SO}_{4}, \mathrm{MgCl}_{2}$ and $\mathrm{MgSO}_{4}$ on the distribution of various carbohydrate fractions were studied in corn seedlings during early stages of growth.

The changes in carbohydrate fractions of corn seeds germinated in water for 54 hours are given in Table 1 . As compared with initial values found in air-dry seeds, there is a decrease in polysaccharide content amounting to $3.8 \mathrm{~g}$, and a simultaneous increase in reducing sugars, sucrose and other nonreducing sugars amounting collectively to $0.23 \mathrm{~g}$. This indicates that the polysaccharides are hydrolysed to simpler sugars and part of these sugars are lost in metabolic activities or by leaching out of the grains. This feature of decrease in polysaccharide content 
and increase of soluble sugars continues till the end of the experiment. Thus, after 174 hours of growth in water the further loss in polysaccharides amounted to $18.6 \mathrm{~g}$ and the significant gain in all soluble sugars amounted to $4.0 \mathrm{~g}$.

Table 1

Changes in the carbohydrate constituents of corn seeds during germination and growth in distilled water. Values are means of four replicates of 48 seedlings and expressed as $\mathrm{mg}$ glucose equivalent

per 100 seedlings. The error did not exceed $5 \%$

\begin{tabular}{|c|c|c|c|c|c|}
\hline $\begin{array}{c}\text { Form of } \\
\text { sugar } \\
\text { estimated }\end{array}$ & \multicolumn{5}{|c|}{ Time from soaking, h } \\
\cline { 2 - 6 } & 0 & 54 & 78 & 126 & 174 \\
\hline $\begin{array}{c}\text { Reducing } \\
\text { sugars }\end{array}$ & 68 & 172 & 920 & 1843 & 2120 \\
$\begin{array}{c}\text { Sucrose } \\
\text { Other non- } \\
\text { reducing }\end{array}$ & 200 & 340 & 390 & 1625 & 1861 \\
$\begin{array}{c}\text { sugars } \\
\text { Polysaccha- } \\
\text { rides }\end{array}$ & 165 & 160 & 200 & 400 & 465 \\
$\begin{array}{c}\text { Total car- } \\
\text { bohydra- } \\
\text { tes }\end{array}$ & 26262 & 22428 & 15702 & 11702 & 7643 \\
\hline
\end{tabular}

The results in Figs. 1 and 2 show the distribution of carbohydrate fractions among the organs of the same seedling 174 hours after soaking. It is clear that the highest content of carbohydrate fractions was still in the grains and the lowest in the roots. The percent of total carbohydrates present in the various organs, relative to that in the whole seedling was: 77 per cent in the grains, 14 per cent in the tops and 9 per cent in the roots. The reducing sugars were: 56 per cent in the grains, 27 per cent in the tops and 17 per cent in the roots. All other carbohydrate fractions were found in the same order of distribution, though in different proportions.

The trend of the effect of various salts on the carbohydrate content of corn grains (Table 2) was as follows:

1. Total carbohydrates and polysaccharide content of salt-treated seedlings was similar to that of the control, i.e. a progressive drop as the seedling becomes older, but the magnitude of the drop was different. With increase of salt concentration there was a less marked drop in the content of these carbohydrates. For example, in the seedlings grown in water there was a fall in the polysaccharide content from $22.4 \mathrm{~g}$ in 54-hour seedlings to $15.7 \mathrm{~g}$ in 78-hour seedlings. Whereas, in seedlings cultured in $10 \mathrm{meq} / \mathrm{l}$ of salt solutions, the values attained after 78 hours were about 20.8, 18.6, 18.0 and $17.4 \mathrm{~g}$ in $\mathrm{NaCl}, \mathrm{Na}_{2} \mathrm{SO}_{4}, \mathrm{MgCl}_{2}$ and $\mathrm{MgSO}_{4}$, respectively. The salt treatment reduced the overall consumption of 

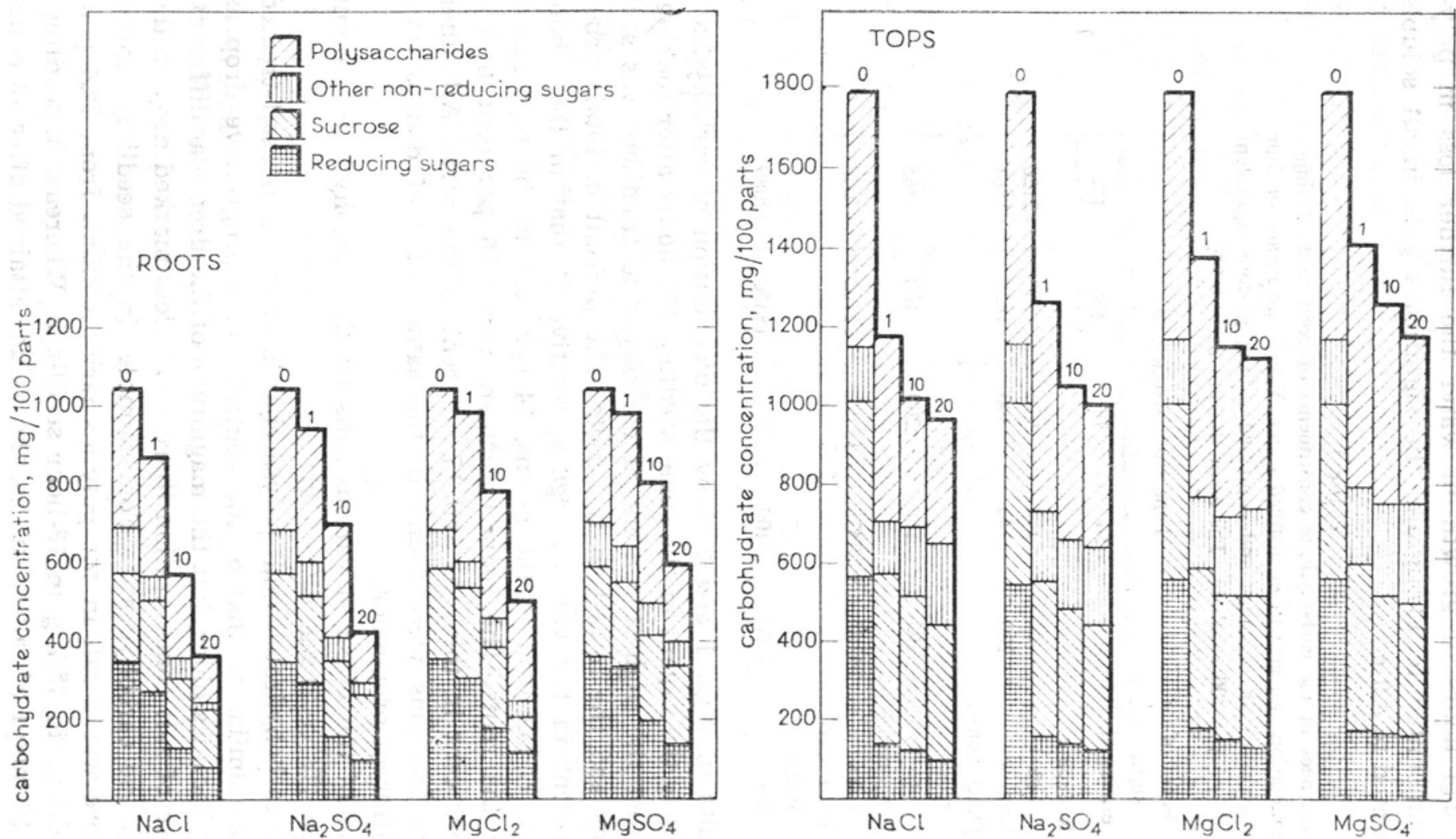

Fig. 1. Effects of different concentrations of salts $(1,10$ and 20 meq/l) one the distribution of carbohydrates in roots and tops of corn seedlings. Values are means of 4 replicates. The error did not exceed $8 \%$ 
Table 2

Effects of different concentrations of salts on the carbohydrate content of corn seedlings. Values are means of four replicates of 48 seedlings and expressed as mg glucose equivalent per 100 seedlings. The error did not exceed $5 \%$

\begin{tabular}{|c|c|c|c|c|c|c|c|c|c|c|c|c|c|c|}
\hline \multicolumn{2}{|c|}{ Lapse of time (h) from } & \multirow{3}{*}{$\begin{array}{l}\text { Form of sugar } \\
\text { estimated }\end{array}$} & \multirow{2}{*}{\multicolumn{3}{|c|}{$\begin{array}{l}\mathrm{NaCl} \\
\mathrm{meq} / 1\end{array}$}} & \multirow{2}{*}{\multicolumn{3}{|c|}{$\begin{array}{c}\mathrm{Na}_{2} \mathrm{SO}_{4} \\
\mathrm{meq} / \mathrm{l}\end{array}$}} & \multirow{2}{*}{\multicolumn{3}{|c|}{$\begin{array}{l}\mathrm{MgCl}_{2} \\
\mathrm{meq} / 1\end{array}$}} & \multirow{2}{*}{\multicolumn{3}{|c|}{$\begin{array}{c}\mathrm{MgSO}_{4} \\
\mathrm{meq} / \mathrm{l}\end{array}$}} \\
\hline \multirow[t]{2}{*}{ Soaking } & \multirow{2}{*}{$\begin{array}{c}\text { transfer to } \\
\text { salt }\end{array}$} & & & & & & & & & & & & & \\
\hline & & & 1 & 10 & 20 & 1 & 10 & 20 & 1 & 10 & 20 & 1 & 10 & 20 \\
\hline \multirow{5}{*}{78} & \multirow{5}{*}{24} & reducing sugars & 831 & 769 & 703 & 798 & 705 & 681 & 771 & 683 & 652 & 752 & 648 & 612 \\
\hline & & sucrose & 583 & 702 & 816 & 496 & 661 & 743 & 451 & 621 & 709 & 418 & 603 & 689 \\
\hline & & other nonreducing sugars & 272 & 304 & 358 & 251 & 282 & 319 & 238 & 262 & 300 & 203 & 231 & 273 \\
\hline & & pulysaccharides & 18982 & 20828 & 22241 & 18031 & 18641 & 19348 & 17594 & 18005 & 18783 & 16738 & 17390 & 18038 \\
\hline & & total carbohydrates & 20673 & 22603 & 24118 & 19576 & 20289 & 21091 & 19054 & 19571 & 20444 & 18111 & 18872 & 19612 \\
\hline \multirow{5}{*}{126} & \multirow{5}{*}{72} & reducing sugars & 725 & 680 & 615 & 1191 & 892 & 673 & 1335 & 1087 & 893 & 1435 & 1181 & 1038 \\
\hline & & sucrose & 2086 & 2358 & 2581 & 1893 & 2188 & 2400 & 1805 & 2067 & 2200 & 1730 & 1938 & 2100 \\
\hline & & other nonreducing sugars & 589 & 663 & 692 & 552 & 611 & 664 & 508 & 588 & 618 & 468 & 531 & 590 \\
\hline & & polysaccharides & 13968 & 14407 & 15013 & 13185 & 13684 & 14682 & 12235 & 13091 & 14033 & 11523 & 12434 & 13211 \\
\hline & & total carbohydrates & 17368 & 18108 & 18901 & 16821 & 17375 & 18419 & 15883 & 16833 & 17744 & 15156 & 16084 & 16939 \\
\hline \multirow{5}{*}{174} & \multirow{5}{*}{120} & reducing sugars & 678 & 461 & 288 & 1046 & 729 & 581 & 1129 & 884 & 727 & 1219 & 981 & 810 \\
\hline & & sucrose & 1854 & 1902 & 2030 & 1719 & 1762 & 1864 & 1756 & 1910 & 2046 & 1816 & 1978 & 2051 \\
\hline & & other nonreducing sugars & 447 & 458 & 507 & 470 & 485 & 499 & 500 & 530 & 560 & 539 & 594 & 621 \\
\hline & & polysaccharides & 10243 & 10573 & 11726 & 7056 & 9674 & 10638 & 8940 & 9025 & 9613 & 8790 & 8718 & 9166 \\
\hline & & total carbohydrates & 13222 & 13394 & 14551 & 12291 & 12650 & 13582 & 12325 & 12349 & 12946 & 12364 & 12271 & 12648 \\
\hline
\end{tabular}


complex carbohydrates (presumably by reducing hydrolysis and/or respiration).

2. Reducing sugars: in the control the reducing sugars increased markedly with advance of time; in salt-treated seedlings, they increased to some extent after 3 days of treatment; then they decreased markedly till the end of the experiment. The change was more pronounced with increase of salt concentration. The salt treatment led to a decrease in hydrolysis of complex carbohydrates to simpler reducing sugars.

3. Sucrose and other nonreducing sugars: in the salt-treated seedlings, they increased with advance of time as in the control, but there were slight differences in the amounts present. The formation of sucrose and other nonreducing sugars was not markedly interrupted by salinity.

The investigated salts affect the distribution of carbohydrates among the different organs of the 174-hour-old seedlings (Figs. 1 and 2) and there is a clearly different picture than in the seedlings as a whole. As in the control, the highest proportions of all carbohydrate fractions were

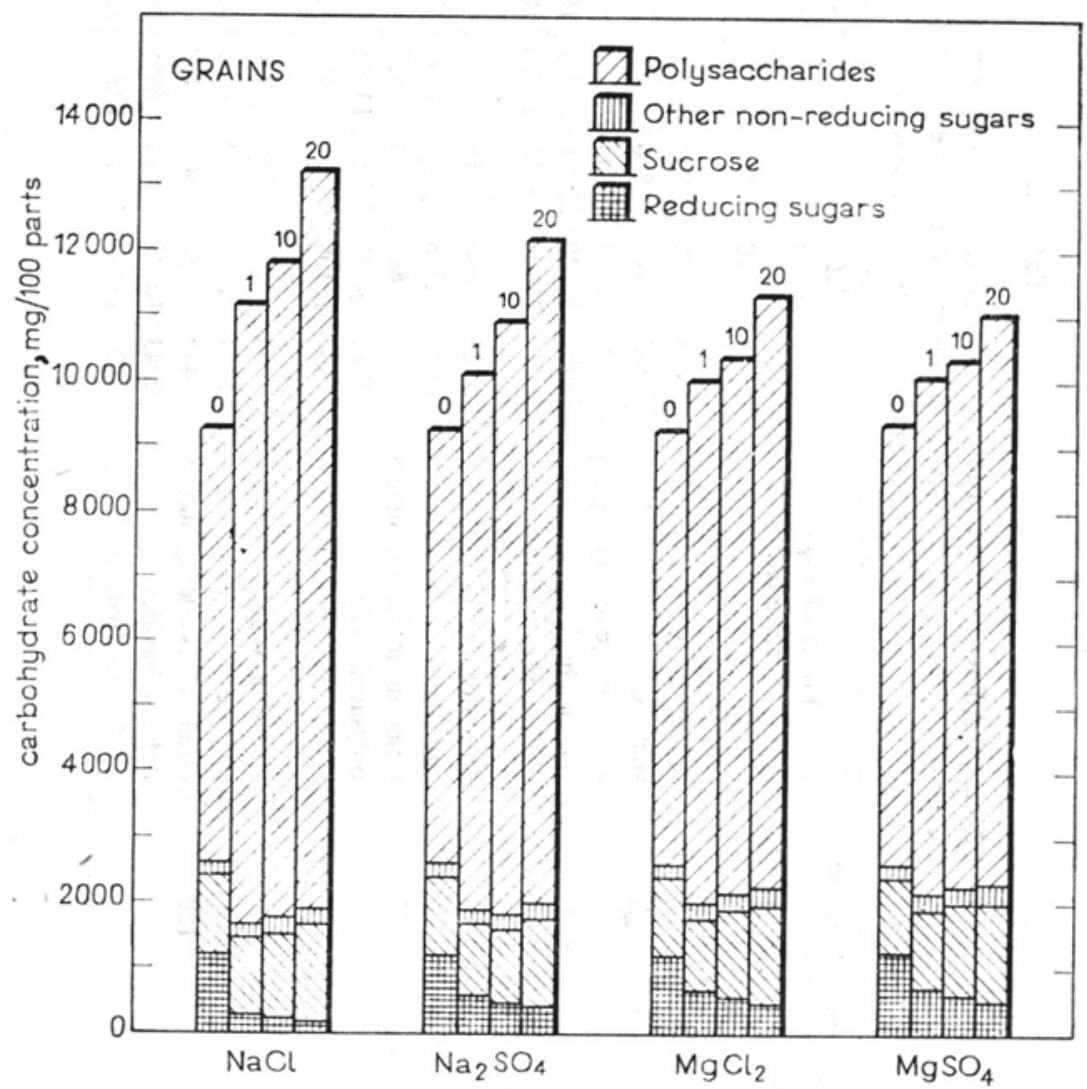

Fig. 2. Effects of different concentrations of salts $(1,10$ and $20 \mathrm{meq} / \mathrm{l})$ on the distribution of carbohydrates in grains of corn seedlings. Values are means of 4 replicates. The error did not exceed $8 \%$ 
found in the grains and the lowest proportions were found in the roots. All the carbohydrate fractions in the roots and tops significantly decreased with increase in salt concentration, except that nonreducing sugars increased in the tops. In the grains the reverse is found, i.e. all carbohydrate fractions, except reducing sugars, increased with increase in salt concentrations. These results indicates that the salts used in this study, besides their effect on hydrolysis of polysaccharides, also suppress the mobilization of various forms of carbohydrates from the grains to the roots and tops.

At equivalent concentrations of the salts investigated we noticed that toxicity was due to both cations and anions. The toxicity effects of sodium were more pronounced than those of magnesium and that of chloride more than of sulphate. This is clear when comparing the effects of $\mathrm{NaCl}$ and $\mathrm{MgCl}_{2}$ on the carbohydrate content of various parts of corn seedlings (Figs. 1 and 2). All carbohydrate fractions are higher in the roots and tops of seedlings grown in $\mathrm{MgCl}_{2}$ salt solution than those in $\mathrm{NaCl}$ salt solutions. The reverse is found true in the grains, being lower in grains derived from seedlings cultured in $\mathrm{MgCl}_{2}$ salt solution than in grains derived from seedlings growing in $\mathrm{NaCl}$ salt solutions, except in those in reducing and other nonreducing sugars. These features suggest that hydrolysis and mobilization of carbohydrates from grain to root and top is more favourable in $\mathrm{MgCl}_{2}$ than in $\mathrm{NaCl}$. The same feature was found when comparing the effects of $\mathrm{NaCl}$ and $\mathrm{Na}_{2} \mathrm{SO}_{4}$ or $\mathrm{MgCl}_{2}$ and $\mathrm{MgSO}_{4}$ and that the toxicity of chlorides was stronger than that of sulphates.

\section{DISCUSSION}

From the results it is evident that the salts investigated affect markedly the carbohydrate metabolism of young corn seedlings. One important feature of the carbohydrate metabolism of corn seedlings was the gradual decrease in the total sugar content with advance of time whether growth was in water or under salinity conditions. But the loss from seeds grown in the salts investigated was consistently less than that from control seedlings. With any salt investigated the values attained at the $1 \mathrm{meq} / \mathrm{l}$ level were almost comparable to those of the nontreated seedlings. The retarding action increased with increase in salt concentration, although the osmotic pressure of the highest concentration used did not exceed $0.92 \mathrm{~atm}$, but this suppressive action was more pronounced with $\mathrm{Na}^{+}$(chloride or sulphate), than with $\mathrm{Mg}^{++}$ (chloride or sulphate). This leads to the conclusion that the catabolic activity of seedlings was greatly retarded owing to the salt effect. Since 
the catabolic activity is controlled by different enzyme systems, one is bound to conclude that $\mathrm{Na}^{+}$and $\mathrm{Mg}^{++}$play their role in affecting the growth of corn seedlings through interference with the activity of certain enzymes (Hewitt 1951, Dix on and W eb b 1961).

The sugar content of the seed axis (root and plumule) increased during germination and growth at the expense of sugars from the endosperm of the grain. Both rates of hydrolysis of nonreducing sugars and of translocation to the developing axis were impaired under salinity conditions, particularly by sodium.

At the same time the amount of sugars retained in the grain was markedly higher in salt-treated seedlings than in control ones. This supports the above conclusion that mobilization of sugars was impaired in salt-treated seedlings. Strogonov and I vanitskaya (1954) reported that the dry weight of seedlings decreased more rapidly in the controls than under salinity conditions and that the mobilization of storage materials was greatly retarded.

Since the anion $\mathrm{Cl}^{-}$exhibited a more suppressive effect on both hydrolysis of nonreducing sugars and mobilization of sugars than the $\mathrm{SO}_{4}^{--}$anion, it may be concluded that toxicity is caused not only by the cation, but the anion also has a certain effect. In wheat grains there is evidence that the toxicity of salts is a function of the properties of the cation since there was no apparent difference in the carbohydrate metabolism of wheat seedlings with the sulphate and chloride anions (H a t a $\mathrm{t}$ a 1975).

The changes in total carbohydrate content run parallel to the changes in dry weight of seedlings during the same period of growth $(\mathrm{H}$ a $\mathrm{t}$ a $\mathrm{t}$ a and $\mathrm{Farah}$ 1982). This feature leads to the conclusion that the catabolic activity of seedling is retarded to some extent as a result of salt treatment. In this connection $\mathrm{G} \mathrm{a} \mathrm{u} \mathrm{ch}$ and $\mathrm{E}$ a to n (1944) and S trogon ov (1958) agree that the carbohydrate content of plants is usually higher under salinity conditions and attributed this to the interference of salts with the utilization of carbohydrate for the formation of new cells and tissues.

Bernstein and Ayers (1953), however, offered another explanation for the accumulation of reserve carbohydrates in carrot plants salinized with $\mathrm{KCl}$ or $\mathrm{NaCl}$. They argued that the salt treatment led to a decrease in growth rate while the net assimilation was not affected markedly. But one should remind here of the complexities which may. arise when photosynthesis is introduced into the field.

$\mathrm{L}$ a p in a (1966) indicated that under conditions of $\mathrm{NaCl}$ salinization, the sucrose content is appreciably increased in the bleeding sap from 
leaves of corn plants. This observation agrees with the above data which indicate that sucrose content of corn seedlings increased with the increase of salt concentration. This fact was taken as an evidence of a substantial disturbances of the carbohydrate metabolism in plants under these conditions.

Zhukovskaya et al. (1972) tried to correlate the effects of salts on carbohydrate metabolism with effects on specific enzymes as aldolase, phosphofructokinase and glucose phosphate isomerase. They hypothesized that salts exert a significant effect on the de novo synthesis of enzymes involved in carbohydrate metabolism and thereby inhibit meristem activity in germinating seeds. The results of the experiments described in this paper indicate clearly that subosmotic concentrations of $\mathrm{Na}$ and $\mathrm{Mg}$ salts such as chlorides or sulphates interfered with the hydrolysis of polysaccharides and with the mobilization of oligo- and monosacharides. This is quite in harmony with the findings of $\mathrm{Zhu}$ kovskaya et al. given above and should stimulate further studies in the field of enzymes concerned with carbohydrate metabolism in response to specific ion treatments.

\section{REFERENCES}

Bernal C. T., Bingham F. T., Oerfili J., 1975. Soil Sci. An. Proc. 38: 777-780.

Bernstein L., A y ers A. D., 1953. Proc. Amer. Soc. Hort. 4: 25-45.

Choon Minkim, 1958. Physiol. Plant. 11: 34-41.

D i x o n M., W e b b E. C., 1961. Enzymes. Longmans. London.

G a u ch H. G., E a t on F. M., 1944. Plant Physiol. 17: 347-352.

Greenway H., Gunn A., Thomas D. A., 1966. Aust. J. Biol. Sci. 19: 741-756. $\mathrm{H}$ a t a t a M. A., 1975. Ph. D. thesis, Faculty of Science, Alexandria University. H a t a t a M. A., F a r a h M., 1982. Acta Soc. Bot. Pol. 51: 71-80.

H e witt E. J., 1951. Ann. Rev. Plant Physiol. 2: 25-52.

I t a i C., R i chmond A., V a a d i a Y., 1968. Israel J. Bot. 17: 187-195.

Karmoker J. L., Van Stevenink R. F. M., 1979. Planta 146: 25-30.

La pin a L. P., 1966. Soviet Plant Physiol. Ruhland W. (ed.). 15: 848-893.

S o m o g y i M., 1952. J. Biol. Chem. 195: 19-25.

Strogonov B. F., 1958. Plant and Soil Salinity. Izdatielstvo Akademii Nauk SSSR.

Strogonov B. P., Ivanitskaya E. F., 1954. Fiziologiya Rastenii. (Cited by

Strogonov B. F., 1962. In: Physiological basis of salt tolerance in plants.

A. Poljakoff-Mayber, A. M. Mayer (eds.), Jerusalem. Translation form Russian).

Zhukovskaya N. V., Dzhanibekova L. S. A., Gaidamakina L. F.,

Luts en k E. K., 1972. Soviet Plant Physiol. 19: 517-524. 
Specyficzny wpływ niektórych soli na metabolizm węglowodanowy siewek kukurydzy

\section{Streszczenie}

Badano wpływ chlorków i siarczanów sodu i magnezu na metabolizm węglowodanowy siewek kukurydzy i ich części. W siewkach kontrolnych i hodowanych w różnych stężeniach soli, obserwowano spadek całkowitej zawartości węglowodanów wraz z upływem czasu. Ten spadek był mniej wyraźny w miarę wzrostu stężenia soli. Zasolenie miało zasadniczy wpływ na zmiany w węglowodanach korzeni i ziaren. Korzenie wykazywały najmniejszą proporcję różnych frakcji węglowodanowych. Sugeruje to, że zasolenie znacznie opóźnia przemieszczanie węglowodanów z ziaren do korzeni. Zarówno kationy jak i aniony wpływają na przemianę rezerw węglowodanowych. 